Article

\title{
Chemical Structure and Immunomodulating Activities of an $\alpha$-Glucan Purified from Lobelia chinensis Lour
}

\author{
Xiao-Jun Li ${ }^{1,2,+}$, Wan-Rong Bao ${ }^{2,+}$, Chung-Hang Leung ${ }^{3}$, Dik-Lung Ma ${ }^{4}$, Ge Zhang ${ }^{2}$, \\ Ai-Ping Lu ${ }^{2}$, Shun-Chun Wang ${ }^{1, *}$ and Quan-Bin Han ${ }^{2, *}$ \\ 1 Institute of Chinese Materia Medica, Shanghai University of Traditional Chinese Medicine, \\ Shanghai 201203, China; lixiaojun@hkbu.edu.hk \\ 2 School of Chinese Medicine, Hong Kong Baptist University, Hong Kong 999077, China; \\ wanrong@hkbu.edu.hk (W.-R.B.); zhangge@hkbu.edu.hk (G.Z.); aipinglu@hkbu.edu.hk (A.-P.L.) \\ 3 State Key Laboratory of Quality Research in Chinese Medicine, Institute of Chinese Medical Sciences, \\ University of Macau, Macao 999078, China; duncanleung@umac.mo \\ 4 Department of Chemistry, Hong Kong Baptist University, Hong Kong 999077, China; \\ edmondma@hkbu.edu.hk \\ * Correspondence: shunchunwang@126.com (S.-C.W.); simonhan@hkbu.edu.hk (Q.-B.H.); \\ Tel.: +86-21-5132-1511 (S.-C.W.); +852-3411-2906 (Q.-B.H.) \\ + These authors contributed equally to this work. \\ Academic Editor: Derek J. McPhee \\ Received: 3 May 2016; Accepted: 7 June 2016; Published: 15 June 2016
}

\begin{abstract}
A neutral $\alpha$-glucan, named BP1, with a molecular mass of approximately 9.45 kDa, was isolated from Lobelia chinensis by hot-water extraction, a Q-Sepharose Fast Flow column and Superdex-75 column chromatography. Its chemical structure was characterized by monosaccharide analysis, methylation analysis and analysis of its FT-IR, high performance gel permeation chromatography (HPGPC) and 1D/2D-NMR spectra data. The backbone of BP1 consists of $\rightarrow{ }_{6} \alpha$-D-Glcp ${ }^{1} \rightarrow{ }_{6,3} \alpha$-D-Glcp ${ }^{1} \rightarrow{ }_{6} \alpha$-D-Glcp $\left.{ }^{1}\right) \mathrm{x}-6,3 \alpha-\mathrm{D}-\mathrm{Glcp}^{1}-{ }_{6} \alpha$-D-Glcp $\left.{ }^{1}\right) \mathrm{y} \rightarrow$. The side chains were terminal $\alpha$-D-Glcp ${ }^{1} \rightarrow$ and $\alpha$-D-Glcp ${ }^{1} \rightarrow\left({ }_{6} \alpha\right.$-D-Glcp $\left.{ }^{1}\right) z \rightarrow{ }_{4} \alpha$-D-Glcp ${ }^{1} \rightarrow{ }_{3} \alpha$-D-Glcp ${ }^{1} \rightarrow{ }_{4} \alpha$-D-Glcp ${ }^{1} \rightarrow$ $(x+y+z=5)$, which are attached to the backbone at O-3 of ${ }_{3,6} \alpha-D-G c_{c p}{ }^{1}$. The results of the effect of BP1 on mouse macrophage cell line RAW 264.7 indicate that BP1 enhances the cell proliferation, phagocytosis, nitric oxide production and cytokine secretion in a dose-dependent manner. Because the inhibitor of Toll-like receptor 4 blocks the BP1-induced secretion of TNF- $\alpha$ and IL-6, we hypothesize that $\alpha$-glucan BP1 activates TLR4, which mediates the above-mentioned immunomodulating effects.
\end{abstract}

Keywords: Lobelia chinensis; NMR; RAW 264.7; immunomodulating; TLR4

\section{Introduction}

Lobelia chinensis, commonly known as Chinese lobelia, Herba Lobellae Chinensis, aze mushiro and mizo kakushi, grows wild throughout East Asia. It is one of the most used anti-cancer herbs in Chinese Medicine [1]. Its chemical profile is very complex. The current phytochemical studies have found various types of chemical components, including piperidine alkaloids, coumarins, terpenoids and saponins [2,3]. These chemicals show various biological activities, including anti-bacterial, anti-venom, anticancer, anti-viral and anti-inflammatory activities [4-8]. In addition to these small molecules, this herb has a large amount of polysaccharides, the content of which can reach $25 \%$ by weight of the dry herb [9]. Little is known about the chemistry and bioactivity of the polysaccharides of this herb.

Plant polysaccharides have shown many bioactivities [10,11], whose ability to modulate immune function is popularly considered a major aspect. Many polysaccharides have been reported to be 
able to activate macrophages [12-14], and this activation plays an important role in the immune response. The present study aims to analyze the chemistry of polysaccharides purified from the water extract of Lobelia chinensis and to explore their immune modulating effects on the RAW 264.7 cell line. A neutral $\alpha$-glucan named BP1, with a molecular mass of approximately $9.45 \mathrm{kDa}$ is isolated from Lobelia chinensis, and its chemical structure was characterized by chemical and spectral analyses. BP1 was able to enhance the cell proliferation, phagocytosis, nitric oxide production and cytokine secretion in a dose-dependent manner.

\section{Results and Discussion}

\subsection{Isolation and Purification of BP1}

Separation of the crude polysaccharide from Lobelia chinensis using fast-flow chromatography on Q-Sepharose generated five fractions: water, $0.2 \mathrm{M} \mathrm{NaCl}, 0.4 \mathrm{M} \mathrm{NaCl}, 1.0 \mathrm{M} \mathrm{NaCl}$ and $0.2 \mathrm{M} \mathrm{NaOH}$ fractions (Figure 1A). Further purification of the major fraction $(0.2 \mathrm{M} \mathrm{NaCl}, 598 \mathrm{mg})$ using gel filtration chromatography on Superdex 75 (Figure 1B) yielded a purified polysaccharide, which was shown to be homogeneous in high performance gel permeation chromatography (HPGPC) (Figure 1C). We named this polysaccharide BP1. Its average molecular weight was determined to be approximately $9450 \mathrm{Da}$.
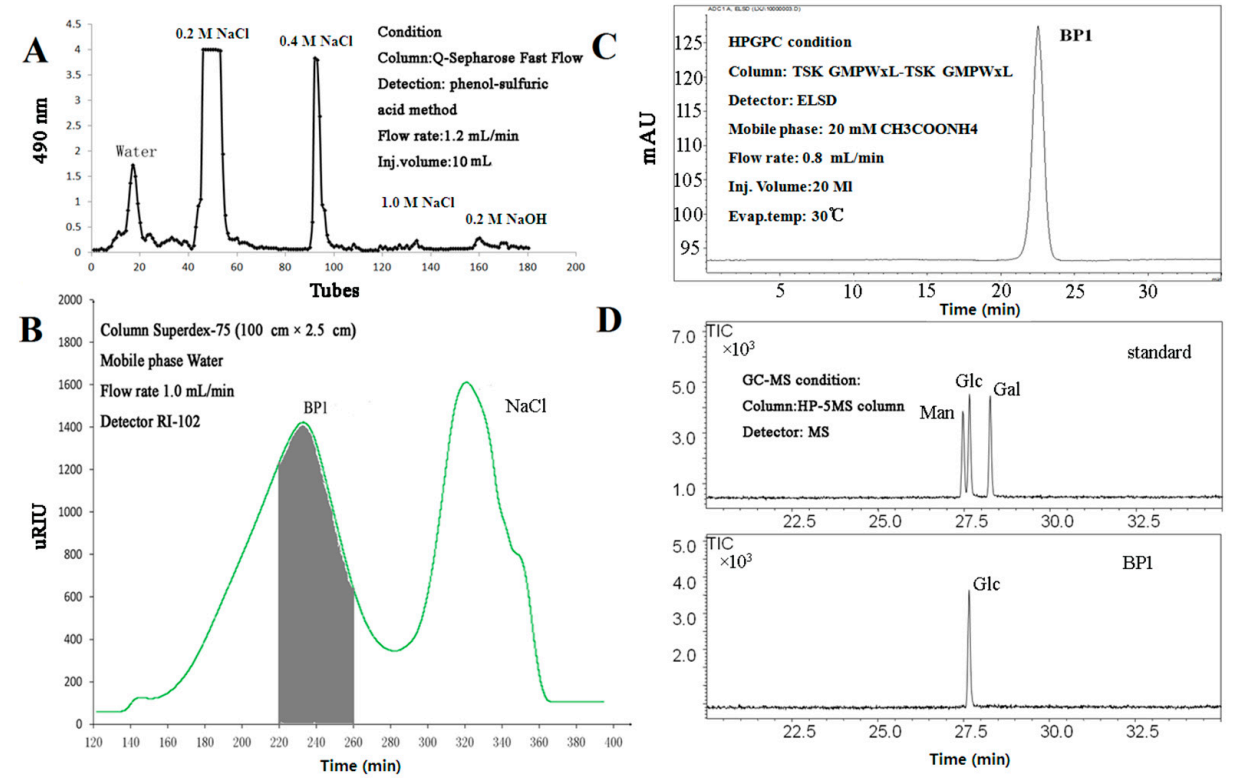

Figure 1. (A) The Q-Sepharose column chromatography of crude polysaccharide extracted from Lobelia chinensis; (B) gel filtration chromatography of the major fraction (0.2 NaCl elution) on Superdex 75; (C) homogeneity of BP1 as measured by high performance gel permeation chromatography (HPGPC);

(D) monosaccharide composition of BP1 (upper: reference standards; lower: BP1).

\subsection{FT-IR Spectral Analysis}

The FT-IR spectra of BP1 (Figure S1) were analyzed as follows [15]: a strong and broad peak at around $3367 \mathrm{~cm}^{-1}$ was attributed to the vibration of the $\mathrm{O}-\mathrm{H}$ bond; a weak absorption peak at approximately $2932 \mathrm{~cm}^{-1}$ was attributed to the stretching vibration of $\mathrm{C}-\mathrm{H}$ bond; these two signals characterized the absorption spectra of polysaccharides. Furthermore, the band at $1639 \mathrm{~cm}^{-1}$ can be attributed to the H-O-H bond, while the signals from $1453 \mathrm{~cm}^{-1}$ to $1332 \mathrm{~cm}^{-1}$ were attributable to $-\mathrm{CH}\left(\mathrm{O}-\mathrm{CH}_{2}\right)$ flexural vibrations, according to $[16,17]$. The band at $1131 \mathrm{~cm}^{-1}$ ws due to the C-O-C bond and glycosidic bridge, and the band at $1200 \mathrm{~cm}^{-1}$ and $1020 \mathrm{~cm}^{-1}$ might be given by the $\mathrm{C}-\mathrm{O}$ stretching vibrations. The band at $846 \mathrm{~cm}^{-1}$ was ascribed to $\alpha$-configuration of the polysaccharide. Absorption at $920 \mathrm{~cm}^{-1}$ indicated the existence of pyranose sugars [18]. 


\subsection{Protein Assay and Monosaccharide Composition Analysis}

BP1 was determined to be protein-free as measured via the Quick Start Bradford Protein Assay. The monosaccharide composition analysis using GC-MS indicated that BP1 was composed of glucose (Figure 1D).

\subsection{Methylation Analysis}

BP1 was subjected to methylation analysis to determine the linkage types $[19,20]$. According to the methylated derivatives, as shown in Table 1, the sugar residues of BP1 were determined to be 2,3,4,6-Me4-Glcp, 2,4,6-Me3-Glcp, 2,3,6-Me3-Glcp, 2,3,4-Me3-Glcp, 2,3-Me2-Glcp, 2,4-Me2-Glcp and 2-Me1-Glcp, indicating the existence of $\mathrm{t}-, 1,6-, 1,4-, 1,3-, 1,3,6-\mathrm{Glc}$, respectively.

Table 1. Linkages and individual molar ratios of BP1 elucidated by methylation analysis.

\begin{tabular}{ccccc}
\hline Methylation Sugars & Linkages & Retention Time (min) & Molar Ratio & \multicolumn{1}{c}{ Main Mass Fragment $\left(m / z^{*}\right.$, Intensity $\left.\%\right)$} \\
\hline 2,3,4,6-Me4-Glcp & Glc-1 & 28.358 & 2.01 & $\begin{array}{l}43(100), 71(20), 87(25), 101(65), 117(50), \\
129(48), 145(40), 161(45), 205(10)\end{array}$ \\
\hline 2,3,4-Me3-Glcp & Glc-1,6 & 36.061 & 5.97 & $\begin{array}{l}43(100), 71(15), 87(33), 99(40), 101(52), 117(55), \\
129(37), 161(15), 173(5), 189(10), 233(10)\end{array}$ \\
\hline 2,3,6-Me3-Glcp & Glc-1,4 & 34.539 & 2.03 & $\begin{array}{l}43(100), 71(5), 87(18), 99(15), 101(20), 113(15), \\
117(45), 129(5), 161(3), 233(20)\end{array}$ \\
\hline 2,4,6-Me3-Glcp & Glc-1,3 & 33.862 & 0.99 & $\begin{array}{l}43(100), 71(16), 87(25), 99(15), 101(38), 113(5), \\
117(85), 129(70), 161(30), 173(5), 233(10)\end{array}$ \\
\hline 2,4-Me2-Glcp & Glc-1,3,6 & 42.231 & 2.01 & $\begin{array}{l}43(100), 71(5), 87(25), 99(10), 101(5), 117(32), \\
129(45), 189(15), 233(5)\end{array}$ \\
\hline
\end{tabular}

* The symbol $m$ stands for mass and $z$ stands for the charge number of ions. $m / z$ represents mass divided by charge number.

\subsection{NMR and Structure Analysis}

The ${ }^{1} \mathrm{H}$ - and ${ }^{13} \mathrm{C}$-NMR spectra of BP1 were carefully assigned after an integrative consideration of the above-mentioned results, the 1D/2D-NMR spectra of BP1. The results are shown in Table 2.

Table 2. Signal assignments of the ${ }^{1} \mathrm{H}$ - and ${ }^{13} \mathrm{C}-\mathrm{NMR}$ spectra of BP1 based on the analysis of H-HCOSY, HSQC and HMBC spectra [21-24].

\begin{tabular}{|c|c|c|c|c|c|c|c|}
\hline \multirow{2}{*}{$\begin{array}{l}\text { Glycosyl } \\
\text { Residues }\end{array}$} & \multirow{2}{*}{$\begin{array}{l}\mathrm{C1} \\
\mathrm{H} 1\end{array}$} & \multirow{2}{*}{$\begin{array}{l}\mathrm{C} 2 \\
\mathrm{H} 2\end{array}$} & \multirow{2}{*}{$\begin{array}{l}\mathrm{C} 3 \\
\mathrm{H} 3\end{array}$} & \multirow{2}{*}{$\begin{array}{l}\mathrm{C} 4 \\
\mathrm{H} 4\end{array}$} & \multirow{2}{*}{$\begin{array}{l}\mathrm{C} 5 \\
\mathrm{H} 5\end{array}$} & \multicolumn{2}{|c|}{ C6 } \\
\hline & & & & & & H6a & H6b \\
\hline \multirow{2}{*}{ A: ${ }_{6} \alpha$-D-Glcp ${ }^{1}$} & 99.0 & 73.1 & 74.3 & 70.8 & 71.4 & 66.8 & \\
\hline & $4.85 \sim 4.90$ & $3.44 \sim 3.48$ & $3.60 \sim 3.64$ & $3.40 \sim 3.43$ & $3.80 \sim 3.83$ & $3.64 \sim 3.66$ & $3.86 \sim 3.90$ \\
\hline \multirow{2}{*}{ B: ${ }_{3,6} \alpha-D-G l c p^{1}$} & 98.9 & 72.4 & 81.7 & 74.1 & 70.6 & 66.6 & \\
\hline & $4.88 \sim 4.91$ & $3.54 \sim 3.59$ & $3.73 \sim 3.77$ & $3.89 \sim 3.93$ & $3.33 \sim 3.37$ & $3.58 \sim 3.67$ & $3.86 \sim 3.90$ \\
\hline \multirow{2}{*}{ C: ${ }_{4} \alpha$-D-Glcp ${ }^{1}$} & 101.0 & 71.4 & 74.6 & 78.0 & 71.6 & 61.8 & \\
\hline & $5.29 \sim 5.32$ & $3.52 \sim 3.54$ & $3.84 \sim 3.88$ & $3.55 \sim 3.58$ & $3.73 \sim 3.77$ & $3.67 \sim 3.69$ & $3.73 \sim 3.75$ \\
\hline \multirow{2}{*}{$\mathrm{D}:{ }_{3} \alpha-\mathrm{D}-\mathrm{Glcp}{ }^{1}$} & 100.8 & 72.4 & 82.3 & 71.4 & 74.3 & 61.8 & \\
\hline & $5.28 \sim 5.30$ & $3.49 \sim 3.50$ & $3.73 \sim 3.77$ & $3.36 \sim 3.38$ & $3.62 \sim 3.66$ & $3.67 \sim 3.69$ & $3.73 \sim 3.75$ \\
\hline \multirow{2}{*}{ E: $\alpha$-D-Glcp ${ }^{1}$} & 100.6 & 72.7 & 71.4 & 73.9 & 71.5 & 61.6 & \\
\hline & $5.22 \sim 5.26$ & $3.44 \sim 3.48$ & $4.09 \sim 4.12$ & $3.89 \sim 3.92$ & $3.34 \sim 3.38$ & $3.67 \sim 3.69$ & $3.73 \sim 3.75$ \\
\hline
\end{tabular}

The anomeric signals were analyzed firstly. The proton signals around $\delta_{\mathrm{H}} 4.83 \sim 4.95 \mathrm{ppm}$ and $\delta_{\mathrm{H}}$ 5.18 5.35 ppm in the ${ }^{1} \mathrm{H}-\mathrm{NMR}$ spectrum (Figure 2A) exhibited a peak area ratio of about 1.9:1; therefore the signals at $\delta_{\mathrm{H}} 4.83 \sim 4.95 \mathrm{ppm}$ were considered to represent the main linkages of BP1. The anomeric carbon signals at $\delta_{C} 98.5 \sim 100.0 \mathrm{ppm}$ and $\delta_{C} 100.2 \sim 101.4 \mathrm{ppm}$ from ${ }^{13} \mathrm{C}-\mathrm{NMR}$ (Figure 2B) showed a peak area ratio of about 1.76:1, so the signals at $\delta_{C} 98.5 \sim 100$ ppm were attributed to the main anomeric 
carbon signals of BP1. It seems likely that the signals of $\delta_{\mathrm{C}} 98.5 \sim 100.0 / \delta_{\mathrm{H}} 4.83 \sim 4.95$ were generated by 1,6-/1,3,6-linked Glc [21,22,24], which were some of the major linkage types according to methylation analysis (Table 1). This deduction was confirmed by the coupling of 98.5 100.0/4.83 4.95 in the HSQC spectrum (Figure 3B). The signals of $\delta_{\mathrm{C}} 100.2 \sim 101.4 / \delta_{\mathrm{H}} 5.18 \sim 5.35$ were assigned to 1,3-/1,4-linked Glc and terminal Glc. In addition, compared to the published data of $\beta$-D-glucopyranose $[20,25]$, the anomeric signals of BP1 were significantly shifted up field, which indicated that BP1 has an $\alpha$-configuration [26]. This deduction was confirmed by the NOE interactions between $\mathrm{H} 1$ and $\mathrm{H} 2$ of residues 1,6-, 1,3,6- and 1,4-linked Glc.
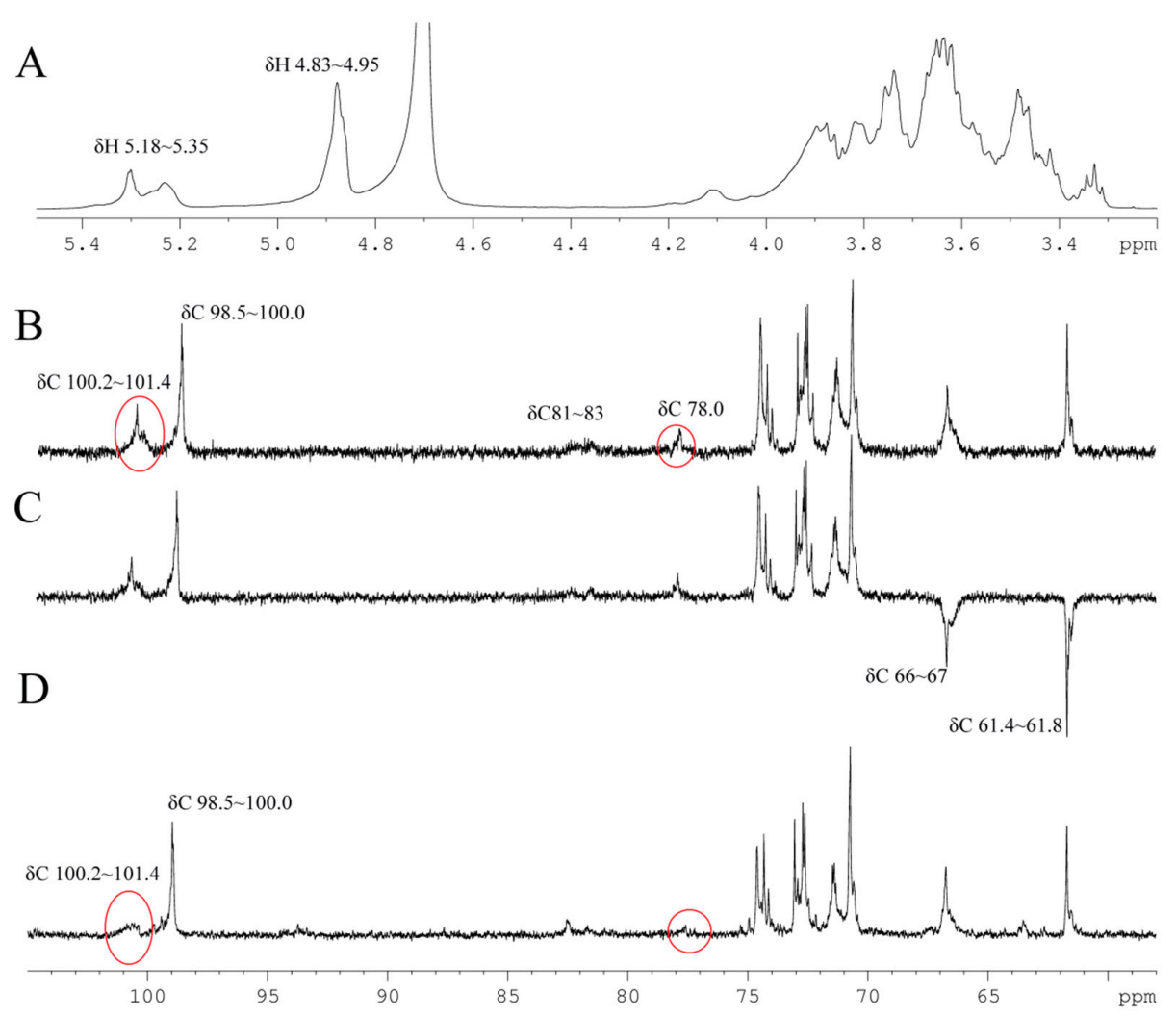

Figure 2. 1D-NMR spectra of BP1. (A) ${ }^{1} \mathrm{H}-\mathrm{NMR}$; (B) ${ }^{13} \mathrm{C}-\mathrm{NMR}$; (C) DEPT135-NMR and (D) ${ }^{13} \mathrm{C}-\mathrm{NMR}$ of BP1a. The signals highlighted in red indicate the changes of $\mathrm{C} 1, \mathrm{C} 3$ of ${ }_{3} \alpha-\mathrm{D}-\mathrm{Glcp}^{1}$ and $\mathrm{C} 4$ of ${ }_{4} \alpha$-D-Glcp ${ }^{1}$ caused by partial acid hydrolysis.

In the DEPT-135 spectrum (Figure 2C), the signals at $\delta_{C} 66 \sim 67$ ppm were most likely due to the $\mathrm{C} 6$ of 1,6-/1,3,6-linked Glc, and the signals at $\delta_{C} 61.4 \sim 61.8 \mathrm{ppm}$ could be attributed to the C6 of 1,3-/1,4-linked Glc and terminal Glc. The signals at $\delta_{C} 78.0$ may belong to the C4 of 1,4-linked Glc [23], while the two peaks at $\delta_{C} 81$ and $\delta_{C} 83$ could be attributed to the C3 of 1,3-linked Glc and 1,3,6-linked Glc, because they were significantly shifted up field compared to the chemical shift of carbon with a free hydroxyl $[27,28]$.

The sequence of the monosaccharides in the sugar chain of BP1 was established by the analysis of the heteronuclear multiple bond correlation (HMBC) spectrum (Figure 3, Table 3). For residue ${ }_{6} \alpha$-D-Glcp ${ }^{1}$, the anomeric proton showed a strong cross peak with the C6 of residue ${ }_{3,6} \alpha-\mathrm{D}-\mathrm{Glcp}^{1}$, and the anomeric carbon of residue ${ }_{6} \alpha-\mathrm{D}-\mathrm{Glcp}^{1}$ also had a strong coupling with $\mathrm{H} 6 \mathrm{~b}$ of residue ${ }_{3,6} \alpha$-D-Glcp ${ }^{1}$, which confirmed the presence of ${ }_{6} \alpha$-D-Glcp ${ }^{1} \rightarrow 6,3 \alpha-D-G l c p^{1}$. The correlation between $\mathrm{C} 1$ of residue ${ }_{3,6} \alpha$-D-Glcp ${ }^{1}$ and H6a of residue ${ }_{6} \alpha-\mathrm{D}-\mathrm{Glcp}^{1}$ and that between the anomeric proton of residue ${ }_{3,6} \alpha-\mathrm{D}-\mathrm{Glcp}^{1}$ with $\mathrm{C} 6 \mathrm{a}$ of residue ${ }_{6} \alpha-\mathrm{D}-\mathrm{Glcp}^{1}$ further indicated the existence of ${ }_{6,3} \alpha$-D-Glcp ${ }^{1} \rightarrow{ }_{6} \alpha$-D-Glcp ${ }^{1}$. These results suggest that the backbone of BP1 was composed of a ${ }_{6,3} \alpha$-D-Glcp ${ }^{1}$ linkage and a ${ }_{6} \alpha$-D-Glcp ${ }^{1}$ linkage. 

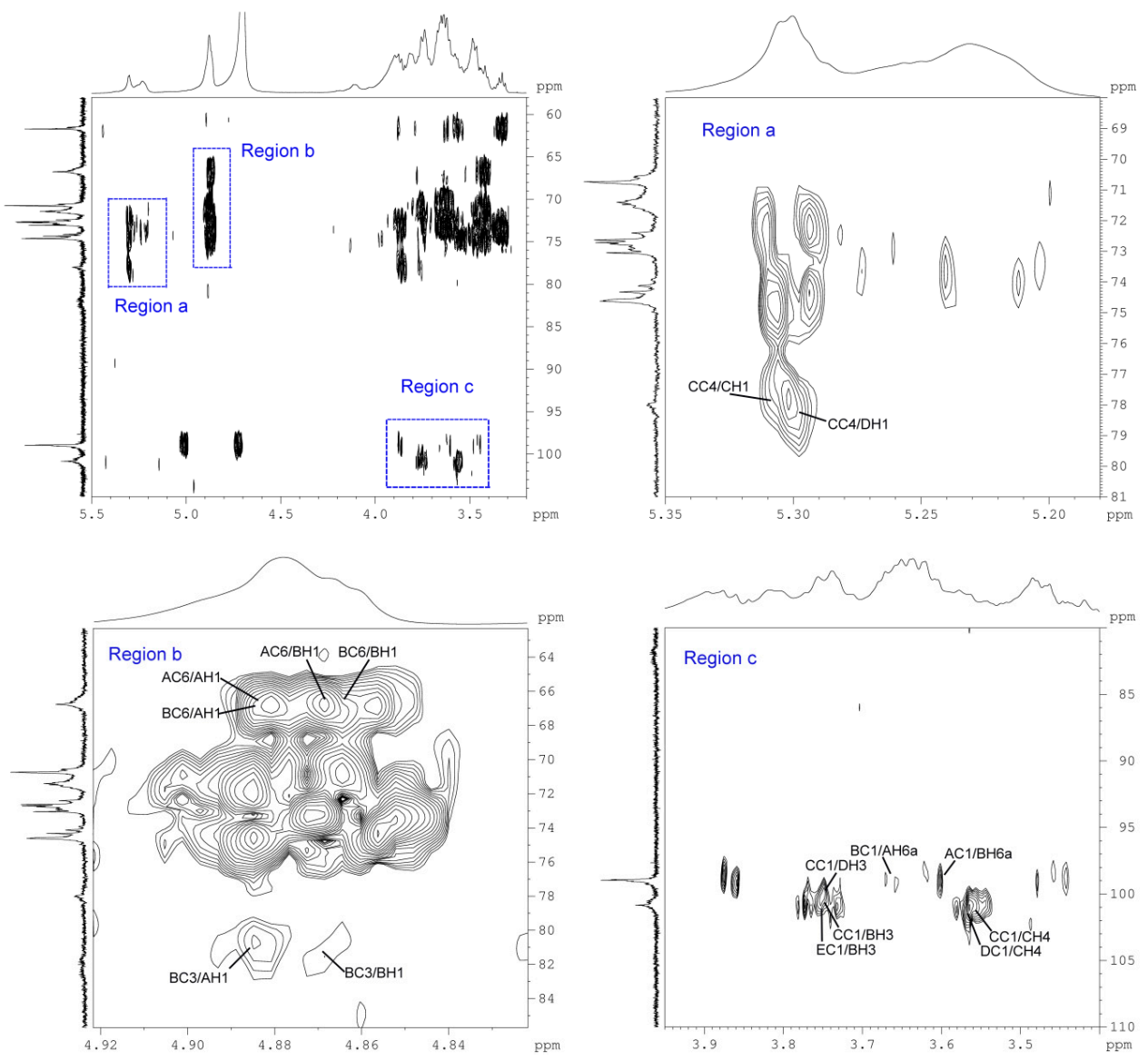

Figure 3. HMBC spectra of BP1: The inter-residue ${ }^{1} \mathrm{H}-{ }^{13} \mathrm{C}$ long-range correlations used for linkage and sequence assignments are listed in Table 3.

Table 3. The significant ${ }^{3} J_{\mathrm{H}, \mathrm{C}}$ correlations observed in the HMBC spectrum of BP1.

\begin{tabular}{|c|c|c|c|c|c|c|c|}
\hline No. & Glycosyl Residues & Atom & Residue & $\delta_{C}$ & Atom & Residue & $\delta_{\mathbf{H}}$ \\
\hline \multirow{7}{*}{ A } & ${ }_{6} \alpha-\mathrm{D}-\mathrm{Glcp}{ }^{1}$ & AH1 & $\mathrm{AC}^{\mathrm{a}}$ & 74.6 & $\mathrm{AC} 1$ & $\mathrm{AH} 2$ & $3.44 \sim 3.48$ \\
\hline & 4.88 & AH1 & $A C 5^{a}$ & 71.4 & $\mathrm{AC} 1$ & AH6a & $3.64 \sim 3.66$ \\
\hline & & AH1 & AC6 & 66.8 & $\mathrm{AC} 1$ & BH6a ${ }^{b}$ & $3.56 \sim 3.61$ \\
\hline & & AH1 & $\mathrm{BC} 3$ & 81.7 & $\mathrm{AC} 1$ & CC3 & $3.84 \sim 3.88$ \\
\hline & & AH1 & $\mathrm{BC} 6^{\mathrm{b}}$ & 66.6 & & & \\
\hline & & AH1 & $\mathrm{CC} 2$ & 71.4 & & & \\
\hline & & AH1 & $\mathrm{CC} 3$ & 74.6 & & & \\
\hline \multirow{6}{*}{ B } & ${ }_{3,6} \alpha-\mathrm{D}-\mathrm{Glcp}^{1}$ & BH1 & $\mathrm{AC} 2$ & 73.1 & $\mathrm{BC} 1$ & $\mathrm{AH} 6 \mathrm{a}^{\mathrm{c}}$ & $3.64 \sim 3.66$ \\
\hline & 4.87 & BH1 & $\mathrm{AC} 4$ & 70.8 & $\mathrm{BC} 1$ & BH6a & $3.56 \sim 3.61$ \\
\hline & & $\mathrm{BH} 1$ & $\mathrm{AC} 6^{\mathrm{C}}$ & 66.8 & & & \\
\hline & & BH1 & $B C 3^{a}$ & 81.7 & & & \\
\hline & & $\mathrm{BH} 1$ & $\mathrm{BC} 5^{\mathrm{a}}$ & 70.6 & & & \\
\hline & & BH1 & BC6 & 66.6 & & & \\
\hline \multirow{4}{*}{$\mathrm{C}$} & ${ }_{4} \alpha-\mathrm{D}-\mathrm{Glcp}{ }^{1}$ & $\mathrm{CH} 1$ & $\mathrm{BC} 2$ & 72.4 & CC1 & $\mathrm{DH} 3^{\mathrm{d}}$ & $3.73 \sim 3.77$ \\
\hline & 5.31 & $\mathrm{CH} 1$ & $\mathrm{BC} 3^{\mathrm{e}}$ & 74.6 & $\mathrm{CC} 1$ & $\mathrm{BH} 3^{\mathrm{e}}$ & $3.73 \sim 3.77$ \\
\hline & & $\mathrm{CH} 1$ & DC2 & 72.4 & CC1 & $\mathrm{CH} 4$ & $3.57 \sim 3.58$ \\
\hline & & $\mathrm{CH} 1$ & $\mathrm{CC} 4$ & 78.0 & & & \\
\hline \multirow{4}{*}{$\mathrm{D}$} & ${ }_{3} \alpha$-D-Glcp ${ }^{1}$ & DH1 & $\mathrm{BC} 2$ & 72.4 & DC1 & $\mathrm{CH} 4^{\mathrm{f}}$ & $3.57 \sim 3.58$ \\
\hline & 5.29 & DH1 & $\mathrm{CC} 3$ & 74.6 & & & \\
\hline & & DH1 & DC2 & 72.4 & & & \\
\hline & & DH1 & $\mathrm{CC} 4^{\mathrm{f}}$ & 78.0 & & & \\
\hline $\mathrm{E}$ & $\alpha$-D-Glcp ${ }^{1}$ & EH1 & $\mathrm{BC} 4$ & 74.1 & EC1 & $\mathrm{BH} 3 \mathrm{~g}$ & $3.73 \sim 3.77$ \\
\hline
\end{tabular}

${ }^{a}$ For the presence of $\alpha$-configurations; ${ }^{b}$ For $\rightarrow{ }_{6} \alpha$-D-Glcp ${ }^{1} \rightarrow{ }_{6,3} \alpha$-D-Glcp ${ }^{1} \rightarrow{ }^{c}{ }^{c}$ For $\rightarrow{ }_{6,3} \alpha$-D-Glcp ${ }^{1} \rightarrow{ }_{6} \alpha$-D-Glcp ${ }^{1}$;

${ }^{\mathrm{d}}$ For $\rightarrow{ }_{4} \alpha$-D-Glcp ${ }^{1} \rightarrow{ }_{3} \alpha$-D-Glcp ${ }^{1} \rightarrow$; ${ }^{\text {e }}$ For $\rightarrow{ }_{4} \alpha$-D-Glcp ${ }^{1} \rightarrow{ }_{3,6} \alpha-D-G l c p^{1} \rightarrow ;$ f For $\rightarrow{ }_{3} \alpha$-D-Glcp ${ }^{1} \rightarrow{ }_{4} \alpha-D-G l c p^{1} \rightarrow$;

g For $\alpha$-D-Glcp $\rightarrow_{3,6} \alpha-\mathrm{D}-\mathrm{Glcp}^{1} \rightarrow$. 
Further, the interactions between C1 of residue ${ }_{4} \alpha$-D-Glcp ${ }^{1}$ with H3 of residue ${ }_{3,6} \alpha$-D-Glcp ${ }^{1}$ and between H1 of residue ${ }_{4} \alpha$-D-Glcp ${ }^{1}$ with C3 of residue ${ }_{3,6} \alpha$-D-Glcp ${ }^{1}$ indicated the presence of of ${ }_{4} \alpha$-D-Glcp ${ }^{1} \rightarrow 3,6 \alpha$-D-Glcp ${ }^{1}$, suggesting that the side chain ${ }_{4} \alpha$-D-Glcp ${ }^{1}$ was linked to the backbone at O-3 of the residue ${ }_{3,6} \alpha$-D-Glcp ${ }^{1}$. In addition, C1 of residue ${ }_{4} \alpha$-D-Glcp ${ }^{1}$ also exhibited a strong coupling with $\mathrm{H} 3$ of residue ${ }_{3} \alpha$-D-Glcp ${ }^{1}$, which indicated the presence of ${ }_{4} \alpha$-D-Glcp ${ }^{1} \rightarrow{ }_{3} \alpha$-D-Glcp ${ }^{1}$. The trans-glycosidic correlation between $\mathrm{C} 1$ of residue ${ }_{3} \alpha$-D-Glcp ${ }^{1}$ and $\mathrm{H} 4$ of residue $4 \alpha$-D-Glcp1, together with that between H1 of residue $3 \alpha$-D-Glcp 1 and C4 of residue ${ }_{4} \alpha$-D-Glcp ${ }^{1}$ proved the presence of ${ }_{3} \alpha$-D-Glcp ${ }^{1} \rightarrow_{4} \alpha-D-G l c p^{1}$. Since the ratio of the main residues ${ }_{4} \alpha-D-G l c p^{1}{ }_{3} \alpha-D-G l c p^{1}$ is about 2:1, a fragment of $\rightarrow_{4} \alpha$-D-Glcp ${ }^{1} \rightarrow_{3} \alpha$-D-Glcp ${ }^{1} \rightarrow_{4} \alpha$-D-Glcp ${ }^{1}$ may exist. Furthermore, the peak of ${ }_{4} \alpha$-D-Glcp ${ }^{1} \rightarrow 3,6 \alpha$-D-Glcp ${ }^{1}$ was shown in HMBC, which allows one to infer that a side chain of $\rightarrow_{4} \alpha$-D-Glcp $\rightarrow_{3} \alpha$-D-Glcp ${ }^{1} \rightarrow_{4} \alpha$-D-Glcp ${ }^{1}$ might be connected to the backbone through the O-3 site of ${ }_{3,6} \alpha$-D-Glcp ${ }^{1}$. Finally, the presence of $\alpha$-D-Glcp $\rightarrow_{3,6} \alpha$-D-Glcp ${ }^{1}$ was deduced from the correlation between $\mathrm{C} 1$ of residue $\alpha$-D-Glcp ${ }^{1}$ and H3 of residue ${ }_{3,6} \alpha$-D-Glcp ${ }^{1}$. Another side chain was composed by $\alpha$-D-Glcp ${ }^{1}$, which joined the backbone through the O-3 site of $3,6 \alpha$-D-Glcp ${ }^{1}$.

More evidence regarding the precise structure of the sugar chain of BP1 was found in the NOESY (nuclear Overhauser effect spectroscopy) (Figure 4, Table 4). The NOEs between AH1/BH6ab, DH1/CH4 and EH1/BH3 confirmed the deductions of ${ }_{6} \alpha$-D-Glcp ${ }^{1} \rightarrow 6,3 \alpha$-D-Glcp ${ }^{1}$, ${ }_{3} \alpha$-D-Glcp ${ }^{1} \rightarrow{ }_{4} \alpha$-D-Glcp ${ }^{1}$, and $\alpha$-D-Glcp ${ }^{1} \rightarrow{ }_{3,6} \alpha$-D-Glcp ${ }^{1}$, and NOEs between EH1/AH6ab and AH1/CH4 further confirmed the linkage of $\alpha$-D-Glcp ${ }^{1} \rightarrow{ }_{6} \alpha$-D-Glcp ${ }^{1}$, and ${ }_{6} \alpha$-D-Glcp ${ }^{1} \rightarrow{ }_{4} \alpha$-D-Glcp ${ }^{1}$. Based on the above evidence, the sequence of the residues of $\alpha$-D-Glcp ${ }^{1} \rightarrow{ }_{6} \alpha$-D-Glcp ${ }^{1} \rightarrow{ }_{4} \alpha$-D-Glcp ${ }^{1} \rightarrow$ was proposed.

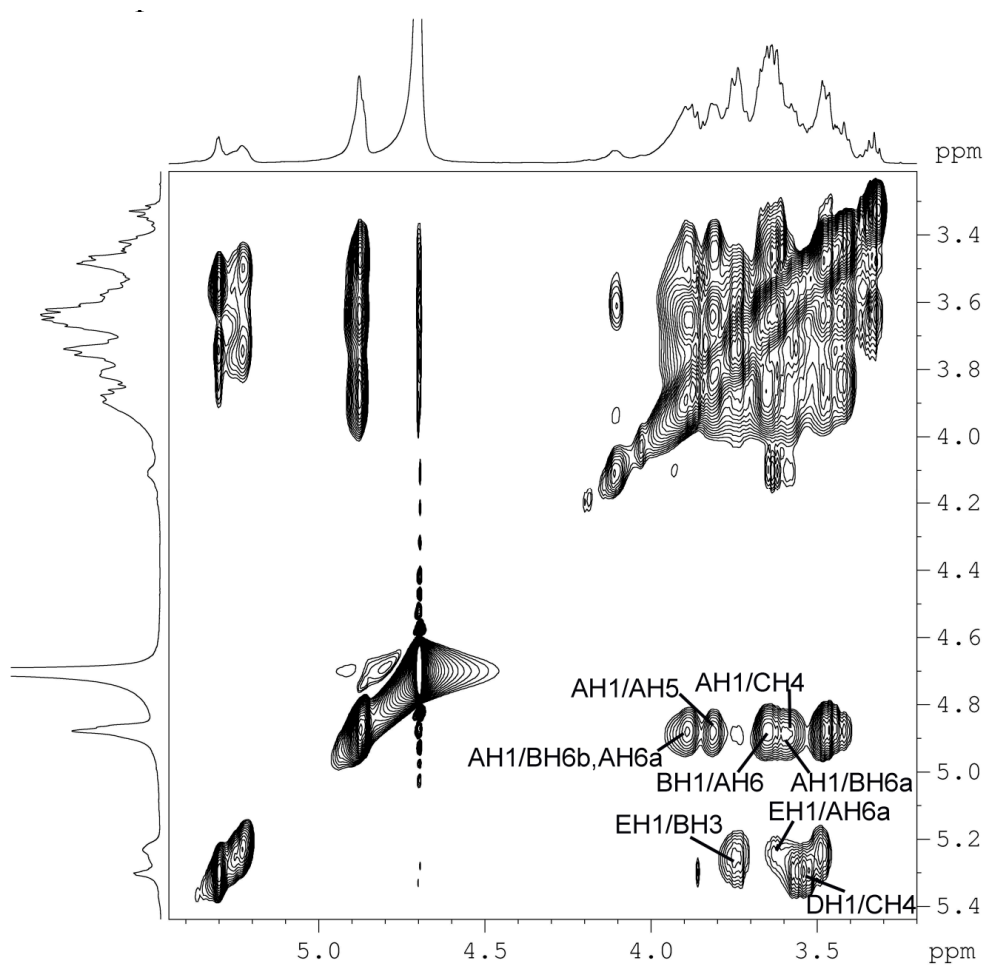

Figure 4. NOESY spectrum of BP1. NOE correlations are labelled with residue and proton/carbon numbers, as listed in Table 4. 
Table 4. Assignment of the NOESY spectra of BP1.

\begin{tabular}{|c|c|c|c|}
\hline Anomeric Proton & NOE Contact Proton & $\delta \mathbf{H}$ & Glycosyl Residue \\
\hline \multirow[t]{7}{*}{ AH1 } & $\mathrm{AH} 2$ & $3.44 \sim 3.48$ & \\
\hline & AH5 & $3.80 \sim 3.83$ & \\
\hline & AH6a & $3.64 \sim 3.66$ & \\
\hline & AH6b & $3.88 \sim 3.90$ & \\
\hline & BH6a & $3.59 \sim 3.61$ & $\rightarrow{ }_{6} \alpha$-D-Glcp ${ }^{1} \rightarrow 6,3 \alpha-$ D-Glcp ${ }^{1} \rightarrow$ \\
\hline & $\mathrm{BH} 6 \mathrm{~b}$ & $3.88 \sim 3.90$ & $\rightarrow{ }_{6} \alpha$-D-Glcp ${ }^{1} \rightarrow 6,3 \alpha$-D-Glcp ${ }^{1} \rightarrow$ \\
\hline & $\mathrm{CH} 4$ & $3.57 \sim 3.58$ & $\rightarrow_{6} \alpha$-D-Glcp ${ }^{1} \rightarrow_{4} \alpha-$-D-Glcp ${ }^{1} \rightarrow$ \\
\hline \multirow[t]{2}{*}{ BH1 } & $\mathrm{BH} 2$ & $3.54 \sim 3.59$ & \\
\hline & BH3 & $3.73 \sim 3.77$ & \\
\hline \multirow[t]{3}{*}{$\mathrm{CH} 1$} & $\mathrm{CH} 2$ & $3.52 \sim 3.54$ & \\
\hline & $\mathrm{CH} 3$ & $3.73 \sim 3.77$ & \\
\hline & $\mathrm{BH} 3$ & $3.73 \sim 3.77$ & \\
\hline DH1 & $\mathrm{CH} 4$ & $3.57 \sim 3.58$ & $\rightarrow_{3} \alpha$-D-Glcp ${ }^{1} \rightarrow_{4} \alpha-$ D-Glcp ${ }^{1} \rightarrow$ \\
\hline DH1 & $\mathrm{CH} 3$ & $3.84 \sim 3.88$ & \\
\hline \multirow[t]{5}{*}{ EH1 } & $\mathrm{BH} 3$ & $3.73 \sim 3.77$ & $\alpha$-D-Glcp ${ }^{1} \rightarrow 3,6 \alpha$-D-Glcp ${ }^{1} \rightarrow$ \\
\hline & $\mathrm{AH} 2$ & $3.44 \sim 3.48$ & \\
\hline & $\mathrm{AH} 3$ & $3.60 \sim 3.64$ & \\
\hline & AH6a & $3.64 \sim 3.66$ & $\alpha$-D-Glcp ${ }^{1} \rightarrow{ }_{6} \alpha$-D-Glcp ${ }^{1} \rightarrow$ \\
\hline & AH6b & $3.88 \sim 3.90$ & $\alpha$-D-Glcp ${ }^{1} \rightarrow{ }_{6} \alpha$-D-Glcp ${ }^{1} \rightarrow$ \\
\hline
\end{tabular}

Taking all the NOE and HMBC evidence together, a side chain of $\alpha$-D-Glcp ${ }^{1} \rightarrow{ }_{6} \alpha$-D-Glcp ${ }^{1}$ $\rightarrow_{4} \alpha$-D-Glcp ${ }^{1} \rightarrow_{3} \alpha$-D-Glcp ${ }^{1} \rightarrow_{4} \alpha$-D-Glcp ${ }^{1} \rightarrow$ could be proposed, which was confirmed by the analysis of the partial acid hydrolysis of BP1. The anomeric signals at $\delta_{C} 100.2 \sim 101.4$ and 98.5 100.0 ppm showed a peak area ratio of about 1:1.76 in the ${ }^{13} \mathrm{C}-\mathrm{NMR}$ spectrum of BP1 (Figure 2B), and the ratio significantly decreased to 1:3.7 after partial acid hydrolysis (Figure 2D). These results suggest that ${ }_{4} \alpha$-D-Glcp ${ }^{1}$ and ${ }_{3} \alpha$-D-Glcp ${ }^{1}$ could be cut off from the main chain by partial acid hydrolysis, indicating that they might exist as side chains. This deduction was confirmed by the decreased signal around $\delta_{\mathrm{C}}$ $78.0 \mathrm{ppm}$ due to $\mathrm{C} 4$ of ${ }_{4} \alpha$-D-Glcp ${ }^{1}$.

Finally, with the aid of the ${ }^{1} \mathrm{H}_{-}{ }^{1} \mathrm{H}$ COSY spectrum (Figure $5 \mathrm{~A}$ ) and the HSQC spectrum (Figure $5 \mathrm{~B}$ ), the ${ }^{1} \mathrm{D}-\mathrm{NMR}$ data were successfully assigned, and the results are presented in Table 2. The methylation analysis indicated that BP1 mainly consists of residues ${ }_{6} \alpha$-D-Glcp ${ }^{1}$, ${ }_{3,6} \alpha$-D-Glcp ${ }^{1},{ }_{4} \alpha$-D-Glcp ${ }^{1}{ }_{3} \alpha$-D-Glcp ${ }^{1}$ and $\alpha$-D-Glcp ${ }^{1}$. Based on methylation analysis, we concluded that the ratio of the main residues ${ }_{6} \alpha$-D-Glcp ${ }^{1}{ }_{3,6} \alpha$-D-Glcp ${ }^{1}{ }_{4} \alpha$-D-Glcp ${ }_{: 3} \alpha$-D-Glcp ${ }^{1}$ is about 6:2:2:1. Therefore, we may infer that the backbone consists of residues following this order: $\rightarrow{ }_{6} \alpha$-D-Glcp ${ }^{1} \rightarrow 6,3 \alpha$-D-Glcp ${ }^{1} \rightarrow{ }_{6} \alpha$-D-Glcp ${ }^{1}-6,3 \alpha-D-G l c p^{1}{ }_{6} \alpha$-D-Glcp ${ }^{1} \rightarrow$. A side chain is attached to the backbone through O-3 of residue $\mathrm{B}$. There are two branches that were $\alpha$-D-Glcp ${ }^{1} \rightarrow{ }_{6} \alpha$-D-Glcp ${ }^{1} \rightarrow{ }_{4} \alpha$-D-Glcp ${ }^{1} \rightarrow_{3} \alpha$-D-Glcp ${ }^{1} \rightarrow_{4} \alpha$-D-Glcp ${ }^{1} \rightarrow$ and terminal $\alpha$-D-Glcp ${ }^{1} \rightarrow$, which were located at the O-3 site of residue $\mathrm{B}\left(3,6 \alpha\right.$-D-Glcp $\left.{ }^{1}\right)$.

In summary, we conclude that the backbone consists of $\rightarrow_{6} \alpha$-D-Glcp ${ }^{1} \rightarrow 6,3 \alpha$-D-Glcp ${ }^{1}$ $\rightarrow\left({ }_{6} \alpha\right.$-D-Glcp $\left.{ }^{1}\right) \mathrm{x}-6,3 \alpha$-D-Glcp ${ }^{1}-{ }_{6} \alpha$-D-Glcp $\left.{ }^{1}\right) \mathrm{y} \rightarrow$. The side chains were $\alpha$-D-Glcp ${ }^{1} \rightarrow\left({ }_{6} \alpha\right.$-D-Glcp $\left.{ }^{1}\right) \mathrm{z} \rightarrow$ ${ }_{4} \alpha$-D-Glcp ${ }^{1} \rightarrow{ }_{3} \alpha$-D-Glcp ${ }^{1} \rightarrow{ }_{4} \alpha$-D-Glcp ${ }^{1} \rightarrow$ and $\alpha$-D-Glcp ${ }^{1} \rightarrow$, being attached to the backbone at O-3 of ${ }_{3,6} \alpha$-D-Glcp ${ }^{1}$. According to the linkage ratio, as revealed by the methylation analysis, the total sum of $\mathrm{x}, \mathrm{y}$ and $\mathrm{z}$ should be five. Additionally, the molecular weight of BP1 suggested that $\mathrm{n}$ should be $3-4$. The proposed structure is shown in Figure 6. A literature research indicated that the $\alpha$-glucan BP1 is the first purified polysaccharide obtained and identified from Lobelia, even though this genus includes more than 415 species [29]. 

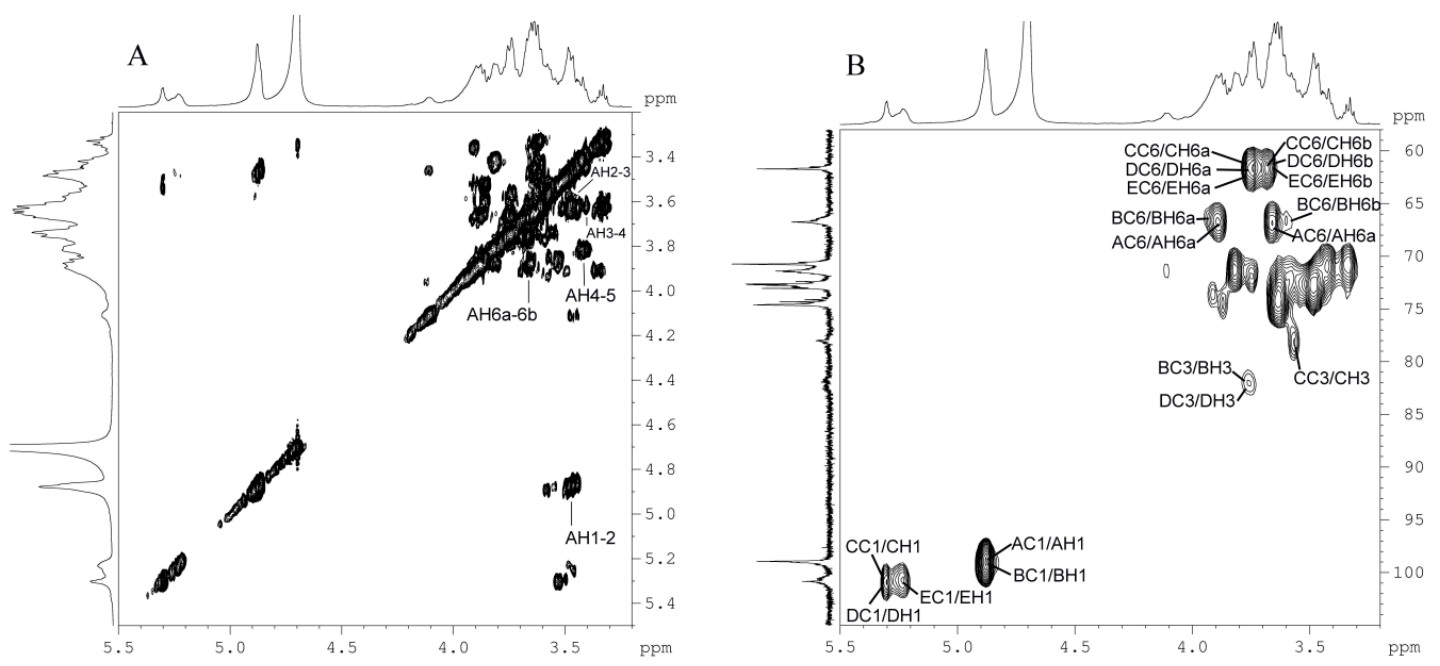

Figure 5. 2D-NMR spectrum of BP1. (A) 1H-1H COSY spectra of BP1; (B) HSQC spectra of BP1. The cross-peaks are labelled with the residue and number; residue names are the same as those in Table 2.

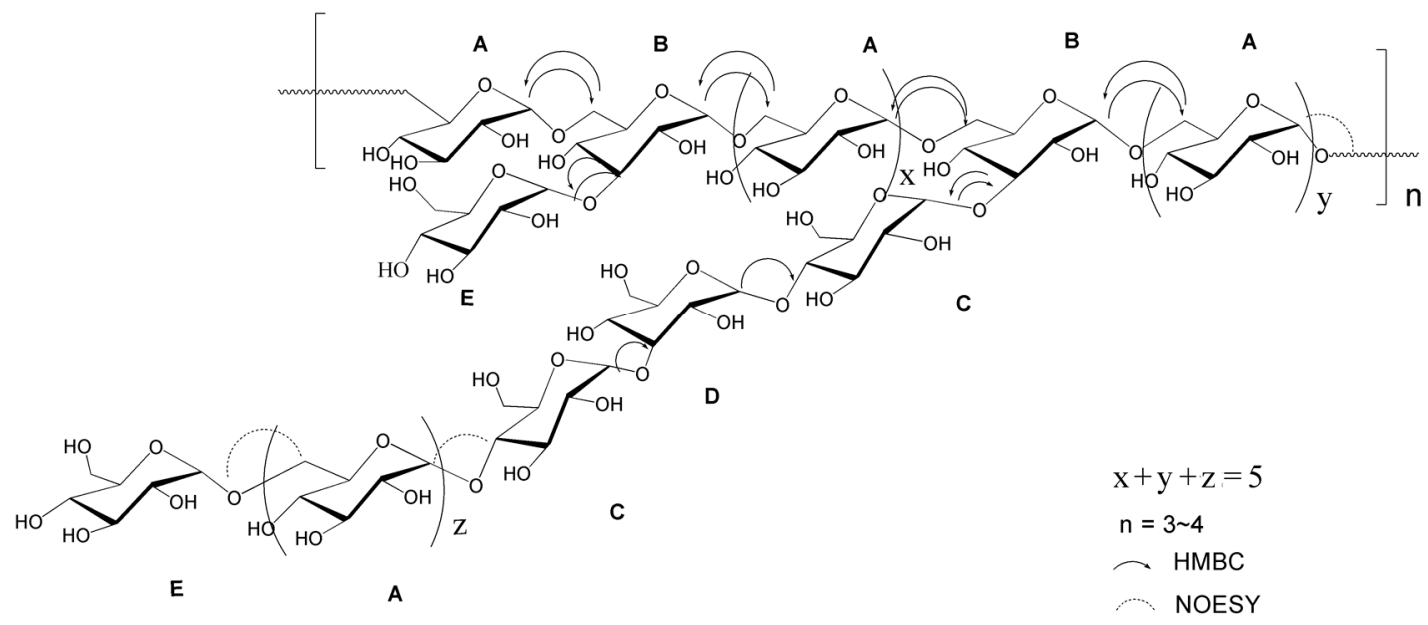

Figure 6. The proposed chemical structure of BP1. (A) ${ }_{6} \alpha$-D-Glcp ${ }^{1}$; (B) ${ }_{3,6} \alpha-\mathrm{D}-\mathrm{Glcp}^{1} ;(\mathbf{C})_{4} \alpha-\mathrm{D}-\mathrm{Glcp}^{1}$; (D) ${ }_{3} \alpha$-D-Glcp ${ }^{1}$; (E) $\alpha$-D-Glcp ${ }^{1}$. The symbols of $x, y$ and $z$ were used to express the number of ${ }_{6} \alpha-\mathrm{D}-\mathrm{Glcp}^{1}$.

\subsection{MTT Assay}

The results of the MTT assay of BP1's effect on the cell proliferation of RAW 264.7 cells are shown in Figure 7A. The positive control LPS induced cell proliferation, and polymyxin B (PolyB) stopped it. Like LPS, BP1 showed significant induction of the proliferation of RAW 264.7 cells, in a dose-dependent manner at concentrations of 12.5, 25,50,100 $\mu \mathrm{g} / \mathrm{mL}$, when administered together with PolyB in order to suppress the effect of LPS. The results suggest that LPS's impact could be excluded in the case of BP1.

\subsection{Effect of BP1 on NO Release by RAW 264.7 Cells}

In this study, the release of NO by RAW 264.7 cells after incubation with different concentrations of BP1 was determined (Figure 7B). As happens with LPS, BP1 also induced a strong NO release in a dose-dependent manner within the varied concentrations of 12.5, 25, 50, $100 \mu \mathrm{g} / \mathrm{mL}$. PolyB inhibited the effect of LPS, but did not affect that of BP1. 

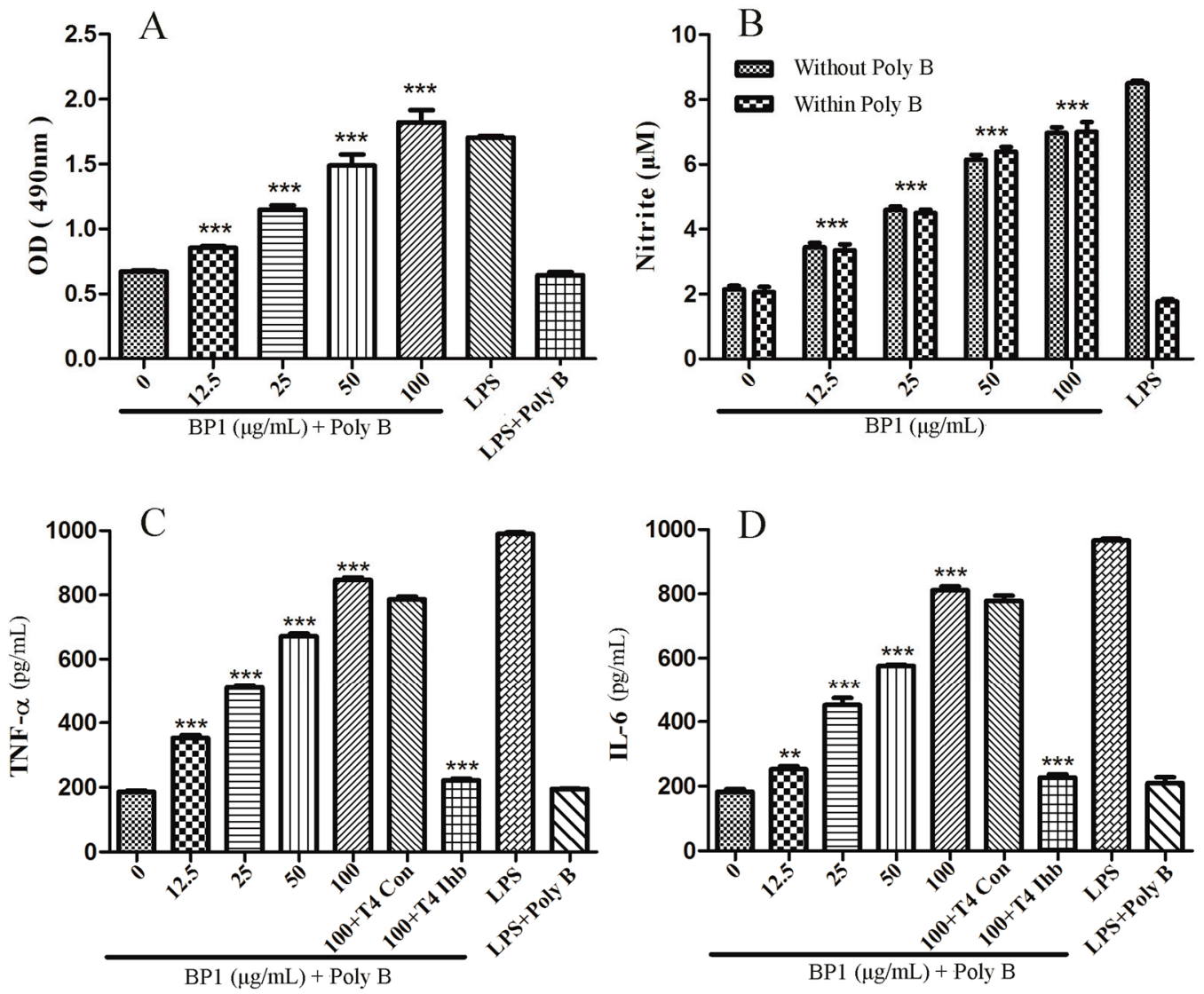

Figure 7. Immunomodulating effects of BP1. (A) Dose-dependent induction of the proliferation of RAW 264.7 cells; (B) dose-dependent effect on the production of NO by RAW 264.7 cells in vitro; (C) induction of RAW 264.7 cell TNF- $\alpha$ secretion in vitro, and the role of TLR4 in this bioactivity; (D) Induction of RAW 264.7 cell IL-6 secretion in vitro, and the role of TLR4 in this bioactivity. LPS $(2 \mu \mathrm{g} / \mathrm{mL})$ and LPS + polymyxin B (PolyB) served as the positive control and endotoxin-excluded control, respectively. Each value is expressed as the mean $\pm \mathrm{SD}(n=3)$. Level of significance: ${ }^{* *} p<0.01 ;{ }^{* *} p<0.001$ compared to untreated cells (at $0 \mu \mathrm{g} / \mathrm{mL}$ ).

\subsection{Cytokine Production and the Role of TLR 4}

Similar results were obtained in the determination of the effects of LPS and BP1 on the secretion of TNF- $\alpha$ and IL-6 by RAW 264.7 cells. LPS and LPS plus PolyB served as positive and endotoxin-excluded controls, respectively. The levels of TNF- $\alpha$ and IL- 6 increased after LPS treatment and after BP1 + PolyB treatment (Figure 7C,D). When administrated with PolyB in order to suppress the effect of LPS, BP1 induced dose-dependent increases over the concentration range of $12.5,25,50,100 \mu \mathrm{g} / \mathrm{mL}$. Furthermore, when Toll-like receptor TLR 4 inhibitor (T4 Ihb) was added to the high-dose BP1 group $(100 \mu \mathrm{g} / \mathrm{mL})$, the production of both TNF- $\alpha$ and IL-6 was significantly suppressed, but the TLR 4 control (100 + T4 Con) did not show such significant difference. These results suggested that TLR 4 may play an important role in the signal transduction.

\subsection{Assay of Phagocytosis}

The effect of BP1 on the phagocytosis to FITC-dextran by RAW 264.7 cells is shown in Figure 8. LPS and LPS plus PolyB served as positive and endotoxin-excluded controls, respectively. LPS at $2 \mu \mathrm{g} / \mathrm{mL}$ significantly induced the phagocytosis, and PolyB stopped it. BP1 at concentrations of 200 and $400 \mu \mathrm{g} / \mathrm{mL}$, when administrated with PolyB in order to suppress the impact of LPS, induced the phagocytosis to FITC-dextran by RAW 264.7 cells. 


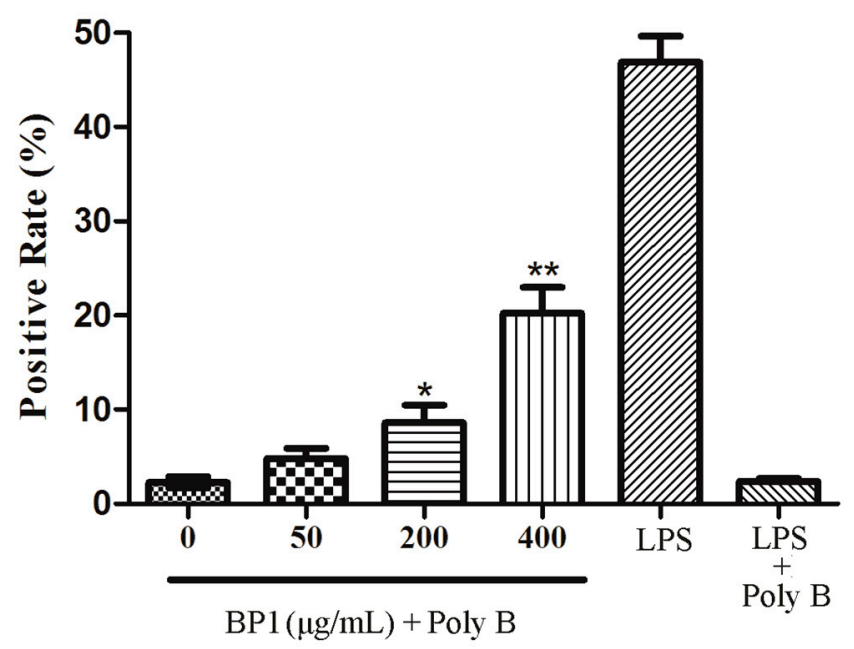

Figure 8. Inducing the effect of BP1 on the phagocytosis to FITC-labeled dextran (12 kDa) by RAW 264.7 cells in a dose-dependent manner. LPS $(2 \mu \mathrm{g} / \mathrm{mL})$ and LPS + polymyxin B served as the positive control and endotoxin-excluded control, respectively. Each value is expressed as the mean $\pm \mathrm{SD}(n=3)$. Level of significance: ${ }^{*} p<0.05,{ }^{* *} p<0.01$ compared to untreated cells (at $0 \mu \mathrm{g} / \mathrm{mL}$ ).

Generally speaking, the bioactivities of polysaccharides are closely dependent on their structures, including monosaccharide composition and sequence, glucosidic bonds, configuration and chain conformation [30-32]. However, it has not been clear if the pattern-recognition receptors of the cell membrane might be specific to the $\alpha, \beta$-configuration of polysaccharides. It has been known that Dectin-1 is the receptor responsible for the recognition of both $\beta-(1,3)$ glucans [33] and $\alpha-(1,3)$ glucans [34]. TLR2 is the receptor responsible for the recognition of both $\beta-(1,3)$ glucans [35] and $\alpha-(1,4)$ glucans [36]. TLR4 is the receptor responsible for the recognition of $\alpha-(1,4,6)$-glucan [37]. In this study, TLR4 was found to be a potential receptor for the $\alpha$-glucan BP1. Because it is not known whether TLR4 functions as a receptor for $\beta$-glucan, we cannot say whether TLR4 is configuration-specific. Therefore, some more research is still needed to determine the role of TLR4 in the immuno-modulating effects of $\beta$-glucans.

\section{Materials and Methods}

\subsection{Materials}

Samples of Herba Lobellae Chinensis, i.e., dried Lobelia chinensis, were provided by the Kang Qiao Traditional Chinese Medicine Decoction Pieces Co. Ltd. (Shanghai, China), China, and were identified by Prof. Zhili Zhao (Shanghai University of Traditional Chinese Medicine, Shanghai, China 131120). Monosaccharide standards were all from Fluka, USA. Dextran standards and trifluoroacetic acid (TFA) and dimethyl sulfoxide (DMSO) were from Sigma-Aldrich (St. Louis, MO, USA). Other reagents were analytical grade and obtained from China Chemical Reagent Industry (Shanghai, China), unless otherwise specified.

\subsection{Isolation and Purification of BP1}

The dried herbs of L. chinensis, samples of approximately $1.0 \mathrm{~kg}$, were weighed accurately, crushed and then refluxed in absolute ethanol at $80^{\circ} \mathrm{C}$ for $2 \mathrm{~h}$. The residues were extracted twice with $5 \mathrm{~L}$ of distilled water at $100^{\circ} \mathrm{C}$ for $3 \mathrm{~h}$. After centrifuging at $4000 \mathrm{rpm}$ for $10 \mathrm{~min}$, the supernatant was collected and condensed to $100 \mathrm{~mL}$ by rotary evaporation at $60^{\circ} \mathrm{C}$. The concentrated solution was precipitated overnight with four volumes of $95 \% \mathrm{EtOH}$ in a refrigerator $\left(4{ }^{\circ} \mathrm{C}\right)$. After centrifuging at $4000 \mathrm{rpm}$ for $10 \mathrm{~min}$, the precipitate was collected and freeze-dried, yielding crude polysaccharides (126 g). 
A part of the crude polysaccharide $(10 \mathrm{~g})$ was dissolved in distilled water $(50 \mathrm{~mL})$ in a water bath at $60{ }^{\circ} \mathrm{C}$ and the solution was centrifuged at 12,000 rpm for $10 \mathrm{~min}$. The above operation was repeated again. The supernatant $(10 \mathrm{~mL})$ was loaded onto a Q-Sepharose Fast Flow column $(50 \mathrm{~cm} \times 5 \mathrm{~cm}$ ), which was eluted stepwise with distilled water, followed by $0.2 \mathrm{M}$ and $0.4 \mathrm{M} \mathrm{NaCl}$ solution and the eluate was monitored using the phenol-sulfuric acid method [38-40]. The major fraction (the part of $0.2 \mathrm{M} \mathrm{NaCl}$ ) was dialyzed with flowing tap-water and freeze-dried using a lyophilizer (Labconco, Kansas City, MO, USA). This fraction was further separated using a Superdex-75 column $(100 \mathrm{~cm} \times 2.5 \mathrm{~cm})$, eluted with $0.2 \mathrm{M} \mathrm{NaCl}$ solution and monitored using an RI-102 refractive index detector (Lihui Biological Technology Co., Ltd., Suzhou, China). The fractions obtained (220-260 $\mathrm{min}$ ) were combined, concentrated, dialyzed against flowing tap-water and lyophilized to obtain the major fraction BP1 (1.25 g).

\subsection{Determination of the Molecular Weight}

The molecular weight of the BP1 was estimated through high performance gel permeation chromatography (HPGPC) (Tosoh Bioscience, King of Prussia, PA, USA) by using combined columns of Shodex KS-802 and KS-804, which were eluted with a mobile phase of $0.2 \mathrm{M} \mathrm{NaCl}$ at a flow rate of $0.8 \mathrm{~mL} / \mathrm{min}$. The eluate was monitored by RI detector (RI-101 refractive index detector). To estimate the molecular weight, Shodex-packed columns were calibrated using a standard P-series of dextrans (P-5, P-10, P-20, P-50, P-100, P-200, P-400 and P-800). The molecular weight was calculated according to the method of Fan et al. and Liu et al. [41,42].

\subsection{Determination of the Protein Content}

The protein contents of the polysaccharide samples were determined using Quick start Bradford $1 \times$ Dye Reagent (Bio-Rad, Hong Kong, China). A standard curve was prepared with bovine serum albumin (BSA, 0-2.0 mg/mL). BP1 polysaccharide was dissolved in deionized water at a concentration of $2.0 \mathrm{mg} / \mathrm{mL}$. The sample was mixed with diluted dye reagent and incubated at room temperature for $5 \mathrm{~min}$. Then, the absorbance was measured at $595 \mathrm{~nm}$ using a microtiter plate reader.

\subsection{Monosaccharide Composition Analysis}

BP1 (2 mg) was hydrolyzed in $2 \mathrm{M}$ TFA $(2 \mathrm{~mL})$ at $120^{\circ} \mathrm{C}$ for $2 \mathrm{~h}$ in a sealed glass tube. The acid was removed under reduced pressure through repeated evaporation with $\mathrm{MeOH}$. The hydrolysate was successively reduced with sodium borohydride, acetylated with acid anhydride $\left(\mathrm{Ac}_{2} \mathrm{O}\right)$ at $105^{\circ} \mathrm{C}$ for $1 \mathrm{~h}$, and the resulting alditol acetates were examined via GC-MS.

The gas chromatography-mass spectrometry (GC-MS) was performed on a Shimadzu QP-2010 instrument equipped with a Shimadzu AOC-20i auto sampler system and interfaced with a Shimadzu QP 2010 S mass spectrometer (Shimadzu Corporation, Tokyo, Japan). Samples were injected in splitless mode on a DB-5 MS analytical column ( $30 \mathrm{~m} \times 0.25-\mathrm{mm}$ ID with a film thickness of $0.25-\mu \mathrm{m}$ J \& W Scientific, Folsom, CA, USA). Helium (purity, 99.999\%) was used as a carrier gas at a constant flow rate of $1 \mathrm{~mL} / \mathrm{min}$. The gas chromatograph was operated in split mode with the split/splitless injector at the ratio of 1:5. The injector temperature was set at $250^{\circ} \mathrm{C}$. The temperature program was set at $140{ }^{\circ} \mathrm{C}$, maintained for $5 \mathrm{~min}$ and increased to $250^{\circ} \mathrm{C}$ for $5 \mathrm{~min}$ at an increment of $3^{\circ} \mathrm{C} / \mathrm{min}$. The mass spectra were taken in SCAN mode at $300 \mathrm{eV}$ from $m / z 40$ to 400 , and the scan speed was 769 while the detector delayed for $5 \mathrm{~min}$. The MS progress started at $5 \mathrm{~min}$ and ended at $44 \mathrm{~min}$. Standard monosaccharides were carried out following the same procedure.

\subsection{Methylation Analysis}

Methylation analysis was carried out according to the modified Hakomori method [43]. Briefly, BP1 $(10 \mathrm{mg})$ was accurately weighed and dissolved in $1.0 \mathrm{~mL}$ of DMSO, to which $1.0 \mathrm{~mL}$ of dimsyl sodium (SMSM, $0.25 \mathrm{~g} / \mathrm{mL}$ ) solution was added under water-free conditions. After incubation under stirring for $12 \mathrm{~h}$ at room temperature, $1 \mathrm{~mL}$ of iodomethane was added slowly into the above 
polysaccharide solution; the solution was kept under incubation in the dark for $5 \mathrm{~h}$ at room temperature. After that, it was dialyzed against flowing tap-water in a dialysis tube (with a molecular size cutoff at $1000 \mathrm{Da}$ ) for $24 \mathrm{~h}$. The methylated polysaccharide was extracted three times with chloroform ( $2 \mathrm{~mL}$ each time); the chloroform extract was combined and dried using a reduced-pressure rotary evaporator. The above procedure was repeated three times, and the completeness of methylation was confirmed when the detection of the hydroxyl absorption in the IR spectrum failed. The methylated polysaccharide was hydrolyzed within 2 M TFA $(2 \mathrm{~mL})$; then, the generated methylated alditol acetates were analyzed by GC-MS. The temperature programming condition of GC was as follows: the column temperature of the column was initially $140{ }^{\circ} \mathrm{C}$ and was increased to $180{ }^{\circ} \mathrm{C}$ at $2{ }^{\circ} \mathrm{C} / \mathrm{min}$, then to $190{ }^{\circ} \mathrm{C}$ at $1{ }^{\circ} \mathrm{C} / \mathrm{min}$ and to $280^{\circ} \mathrm{C}$ at $10^{\circ} \mathrm{C} / \mathrm{min}$ and held for $5 \mathrm{~min}$. The gas chromatograph was operated in split mode with the split/splitless injector at the ratio of 1:5. The injector temperature was set at $250{ }^{\circ} \mathrm{C}$. The MS progress started at $5 \mathrm{~min}$ and ended at $44 \mathrm{~min}$. Standard monosaccharide were carried out following the same procedure.

\subsection{Partial Acid Hydrolysis}

BP1 $(50 \mathrm{mg})$ was dissolved in $5 \mathrm{~mL}$ of TFA $(0.1 \mathrm{M})$ at $60^{\circ} \mathrm{C}$ for $1 \mathrm{~h}$. The hydrolysate solution was evaporated under reduced pressure, and $\mathrm{MeOH}$ was added into the residue to remove TFA. The product was lyophilized and dissolved in ultra-pure water. The degraded polysaccharide was isolated from the hydrolysis products by ethanol precipitation and was named BP1a, which was examined using HPGPC before the NMR test [44].

\subsection{NMR Analysis}

The ${ }^{1} \mathrm{H}-\mathrm{NMR}(400 \mathrm{MHz}),{ }^{13} \mathrm{C}-\mathrm{NMR}(100 \mathrm{MHz}), 2 \mathrm{D}-\mathrm{NMR}$, including ${ }^{1} \mathrm{H}-{ }^{1} \mathrm{H}$ correlation spectroscopy (COSY), heteronuclear single-quantum coherence (HSQC) and heteronuclear multiple bond correlation (HMBC) spectra of BP1, were obtained on a Bruker Avance 400 spectrometer (Bruker BioSpin, Rheinstetten, Germany). BP1 (40 mg) was dissolved in $1 \mathrm{~mL}$ of $\mathrm{D}_{2} \mathrm{O}(99.9 \% \mathrm{D})$ and freeze-dried to complete deuterium exchange. The treated sample was dissolved again in $400 \mu \mathrm{L}$ of $\mathrm{D}_{2} \mathrm{O}(99.9 \% \mathrm{D})$ to make the sample solution. Acetone was used as the internal standard $\left(\delta_{\mathrm{H}} 2.225 \mathrm{ppm}, \delta_{\mathrm{C}} 31.45 \mathrm{ppm}\right)$. The Bruker TopSpin program was used to acquire and process the NMR data.

\subsection{MTT Assay}

The effect of BP1 on the proliferation of RAW 264.7 cells was measured using the MTT (3-[4,5-dimethylthiazol]-2,5-diphenyltetrazolium bromide, Sigma-Aldrich stain assay. Cells $\left(1 \times 10^{4}\right.$ cells / well) were seeded in 96-well plates (Corning Inc., Corning, New York, NY, USA) and cultured overnight; they were then incubated with different concentrations of BP1 plus polymyxin B (PolyB $10 \mu \mathrm{g} / \mathrm{mL}$, used to suppress the effect of LPS) for $24 \mathrm{~h}$. LPS ( $2 \mu \mathrm{g} / \mathrm{mL})$ and LPS plus PolyB $(10 \mu \mathrm{g} / \mathrm{mL})$ were used as controls. Following incubation, $30 \mu \mathrm{L}$ of MTT solution $(5 \mathrm{mg} / \mathrm{mL}$ in PBS) were added to each well, and the plates were incubated at $37^{\circ} \mathrm{C}$ for another $4 \mathrm{~h}$. Then, the medium was discarded, and $150 \mu \mathrm{L}$ of dimethyl sulfoxide was added to dissolve the formazan crystals. The absorbance of each sample was read at $490 \mathrm{~nm}$ using a microplate reader (Thermo, Waltham, MA, USA).

\subsection{Nitrite Assay}

RAW 264.7 macrophages were seeded on a 24-well plate at the initial concentration of $2 \times 10^{5}$ cells/well overnight. The cells were treated with $12.5,25,50$ and $100 \mu \mathrm{g} / \mathrm{mL}$ of BP1 for $24 \mathrm{~h}$. PolyB was added to the cells in order to monitor the impact of LPS. LPS $(2 \mu \mathrm{g} / \mathrm{mL})$ and LPS plus PolyB were used as controls. The production of $\mathrm{NO}$ was determined by assaying the accumulation of nitrite, in the culture medium having Griess reagent (Sigma-Aldrich). The nitrite concentration was calculated by comparison with standard sodium nitrite solutions by spectrophotometry, at $540 \mathrm{~nm}$. 


\subsection{Cytokine Determination and the Effect of Toll-Like Receptor 4 Inhibitor}

The production of tumor necrosis factor-alpha (TNF- $\alpha$ ) and interleukin -6 (IL-6) was measured by using an ELISA kit (eBioscience, San Diego, CA, USA). Briefly, RAW 264.7 macrophages were seeded overnight on a 24 -well plate at the initial concentration of $2 \times 10^{5}$ cells/well. In the groups treated with TLR 4 inhibitor or TLR 4 inhibitor control (Novus Biologicals, Littleton, CO, USA), the cells were pretreated with TLR 4 inhibitor or its control and incubated at $37{ }^{\circ} \mathrm{C}$, in an atmosphere of $5 \% \mathrm{CO}_{2}$. One hour later, PolyB plus different concentrations of BP1 were added to the medium (system), and the cells were incubated for another $24 \mathrm{~h}$. LPS $(2 \mu \mathrm{g} / \mathrm{mL})$ and LPS plus PolyB were used as controls. Cell-free supernatants were collected for the ELISA assay.

\subsection{Phagocytic Assay}

Fluorescein isothiocyanate-conjugated dextran (FITC-dextran, Mw 12,000) was prepared for the phagocytic assay according to a published study [45]. RAW 264.7 macrophages $\left(4 \times 10^{5}\right.$ cells $/$ well $)$ were seeded in 12-well plates overnight and were then exposed to the various concentrations of 12.5, 25, 50 and $100 \mu \mathrm{g} / \mathrm{mL}$ of BP1 for $24 \mathrm{~h}$, in which PolyB $(10 \mu \mathrm{g} / \mathrm{mL})$ was added to all of the cells in order to suppress the impact of LPS. LPS $(2 \mu \mathrm{g} / \mathrm{mL})$ and LPS plus PolyB $(10 \mu \mathrm{g} / \mathrm{mL})$ were tested as controls. After that, all of the media were removed, and the cells were treated with FITC-dextran $(0.1 \mathrm{mg} / \mathrm{mL})$, which was dissolved in the cell culture medium and incubated for $1 \mathrm{~h}$ at $37^{\circ} \mathrm{C}$ in an atmosphere of $5 \%$ $\mathrm{CO}_{2}$. After incubation, cells were washed four times in cold phosphate-buffered saline (PBS) and were analyzed by flow cytometry (BD Biosciences, San Jose, CA, USA).

\subsection{Data Analysis}

All of the results were expressed as the mean \pm SD/SEM. Statistical analysis was performed using one-way ANOVA. Data analysis was performed using GraphPad PRISM software Version 5.0 (GraphPad Software, San Diego, CA, USA). A value of $p<0.05$ was chosen as the criterion of statistical significance.

\section{Conclusions}

A neutral $\alpha$-glucan, named BP1, with a molecular mass of approximately $9.45 \mathrm{kDa}$ was isolated from Lobelia chinensis. Its backbone mainly consists a ${ }_{6} \alpha-\mathrm{D}-\mathrm{Glcp}^{1}$ linkage. The side chains are terminal $\alpha$-D-Glcp ${ }^{1} \rightarrow$ and $\alpha$-D-Glcp ${ }^{1} \rightarrow\left({ }_{6} \alpha \text {-D-Glcp }{ }^{1}\right)_{z} \rightarrow{ }_{4} \alpha$-D-Glcp ${ }^{1} \rightarrow{ }_{3} \alpha$-D-Glcp ${ }^{1} \rightarrow{ }_{4} \alpha$-D-Glcp ${ }^{1} \rightarrow$, which are attached to the backbone at O-3 of ${ }_{3,6} \alpha-\mathrm{D}-\mathrm{Glcp}^{1}$. BP1 is able to enhance the cell proliferation, phagocytosis, nitric oxide production and cytokine secretion of RAW 264.7 cells in a dose-dependent manner. These effects might be mediated via TLR4, as the inhibitor of TLR4 is able to block the BP1-induced secretion of TNF- $\alpha$ and IL-6.

Supplementary Materials: Supplementary materials can be accessed at: http://www.mdpi.com/1420-3049/21/ 6/779/s1.

Acknowledgments: This study was supported by the National Nature Science Foundation of China (No. 81473341) and the Hong Kong Government General Research Fund (No. 22100014).

Author Contributions: X.-J.L. and Q.-B.H. designed the experiments. X.-J.L. and W.-R.B. performed the experiments. C.-H.L., D.-L.M., G.Z., A.-P.L. and S.-C.W. contributed in data analysis. X.-J.L. and W.-R.B. wrote the manuscript, and Q.-B.H. revised the manuscript.

Conflicts of Interest: The authors declare no conflict of interest.

\section{References}

1. Yong, Z.; Lei, Z. Research progress in Lobelia chinensis. Med. Inform. 2006, 19, 1115-1116.

2. Chen, M.W.; Chen, W.R.; Zhang, J.M.; Long, X.Y.; Wang, Y.T. Lobelia chinensis: Chemical constituents and anticancer activity perspective. Chin. J. Nat. Med. 2014, 12, 103-107. [PubMed] 
3. Yang, S.; Shen, T.; Zhao, L.; Li, C.; Zhang, Y.; Lou, H.; Ren, D. Chemical constituents of Lobelia chinensis. Fitoterapia 2014, 93, 168-174. [CrossRef] [PubMed]

4. Shi, L.; Wang, J.X.; Li, Y.Y.; Kang, W.Y. Studies on biological activity of compound recipe of Lobelia chinensis. Chin. J. Exp. Tradit. Med. Form. 2010, 16, 57-61.

5. Kuo, P.C.; Hwang, T.L.; Lin, Y.T.; Kuo, Y.C.; Leu, Y.L. Chemical constituents from Lobelia chinensis and their anti-virus and anti-inflammatory bioactivities. Arch. Pharm. Res. 2011, 34, 715-722. [CrossRef] [PubMed]

6. Kuo, Y.C.; Lee, Y.C.; Leu, Y.L.; Tsai, W.J.; Chang, S.C. Efficacy of orally administered Lobelia chinensis extracts on herpes simplex virus type 1 infection in balb/c mice. Antivir. Res. 2008, 80, 206-212. [CrossRef] [PubMed]

7. Shao, J.H.; Zhang, H. Influence of Lobelia chinensis lour. Decoction on expression of C-erbB-2 and P53 on H22 tumor-bearing mice. Chin. J. Clin. Pharm. 2010, 19, 372-375.

8. Wang, H.Y.; Quan, K.; Jiang, Y.L.; Wu, J.G.; Tang, X.W. Effect of luteolin and its combination with chemotherapeutic drugs on cytotoxicity of cancer cells. J. Zhejiang Univ. Med. Sci. 2010, 39, 30-36.

9. Huang, X.X.; Lai, H.F.; Luo, L.C. Optimization of extraction technology for polysaccharide from Lobelia chinensis by ultrasonic-composite enzyme synergistic method. Chin. J. Exp. Tradit. Med. Form. 2012, 18, 44-46.

10. Yan, J.K.; Wang, W.Q.; Wu, J.Y. Recent advances in Cordyceps sinensis polysaccharides: Mycelial fermentation, isolation, structure, and bioactivities: A review. J. Funct. Foods 2014, 6, 33-47. [CrossRef]

11. Zhu, F.M.; Du, B.; Bian, Z.X.; Xu, B.J. $\beta$-glucans from edible and medicinal mushrooms: Characteristics, physicochemical and biological activities. J. Food Compos. Anal. 2015, 41, 165-173. [CrossRef]

12. Xie, S.Z.; Hao, R.; Zha, X.Q.; Pan, L.H.; Liu, J.; Luo, J.P. Polysaccharide of Dendrobium huoshanense activates macrophages via toll-like receptor 4-mediated signaling pathways. Carbohydr. Polym. 2016, 146, 292-300. [CrossRef] [PubMed]

13. Wang, W.; Zou, Y.; Li, Q.; Mao, R.W.; Shao, X.J.; Jin, D.; Zheng, D.H.; Zhao, T.; Zhu, H.F.; Zhang, L.; et al. Immunomodulatory effects of a polysaccharide purified from Lepidium meyenii walp. On macrophages. Process Biochem. 2016, 51, 542-553. [CrossRef]

14. Huang, J.Q.; Nie, Q.X.; Liu, X.Z.; Zhang, S.S.; Nie, S.P.; Huang, D.F.; Wang, S.A.; Zhu, F.; Xie, M.Y. Ganoderma atrum polysaccharide modulates TNF- $\alpha$ secretion and mRNA expression in macrophages of S-180 tumor-bearing mice. Food Hydrocoll. 2016, 53, 24-30. [CrossRef]

15. Goo, B.G.; Baek, G.; Choi, D.J.; Park, Y.I.; Synytsya, A.; Bleha, R.; Seong, D.H.; Lee, C.G.; Park, J.K. Characterization of a renewable extracellular polysaccharide from defatted microalgae Dunaliella tertiolecta. Bioresour. Technol. 2013, 129, 343-350. [PubMed]

16. Wang, L.C.; Zhang, K.; Di, L.Q.; Liu, R.; Wu, H. Isolation and structural elucidation of novel homogenous polysaccharide from Mactra veneriformis. Carbohydr. Polym. 2011, 86, 982-987. [CrossRef]

17. Zhao, T.; Mao, G.H.; Feng, W.W.; Mao, R.W.; Gu, X.Y.; Li, T.; Li, Q.; Bao, Y.T.; Yang, L.Q.; Wu, X.Y. Isolation, characterization and antioxidant activity of polysaccharide from Schisandra sphenanthera. Carbohydr. Polym. 2014, 105, 26-33. [CrossRef] [PubMed]

18. Cui, H.X.; Liu, Q.; Tao, Y.Z.; Zhang, H.F.; Zhang, L.; Ding, K. Structure and chain conformation of a $(1 \rightarrow 6)-\alpha$-D-glucan from the root of Pueraria lobata (willd.) ohwi and the antioxidant activity of its sulfated derivative. Carbohydr. Polym. 2008, 74, 771-778. [CrossRef]

19. Di, H.; Zhang, Y.; Chen, D. An anti-complementary polysaccharide from the roots of Bupleurum chinense. Int. J. Biol. Macromol. 2013, 58, 179-185. [CrossRef] [PubMed]

20. Zhu, H.; Di, H.; Zhang, Y.; Zhang, J.; Chen, D. A protein-bound polysaccharide from the stem bark of Eucommia ulmoides and its anti-complementary effect. Carbohydr. Res. 2009, 344, 1319-1324. [CrossRef] [PubMed]

21. Han, X.Q.; Wu, X.M.; Chai, X.Y.; Chen, D.; Dai, H.; Dong, H.L.; Ma, Z.Z.; Gao, X.M.; Tu, P.F. Isolation, characterization and immunological activity of a polysaccharide from the fruit bodies of an edible mushroom, Sarcodon aspratus (berk.) s. Ito. Food Res. Int. 2011, 44, 489-493. [CrossRef]

22. Villares, A.; García-Lafuente, A.; Guillamón, E.; Mateo-Vivaracho, L. Separation and characterization of the structural features of macromolecular carbohydrates from wild edible mushrooms. Bioact. Carbohydr. Diet. Fibre 2013, 2, 15-21. [CrossRef] 
23. Wu, Y.L.; Sun, C.R.; Pan, Y.J. Studies on isolation and structural features of a polysaccharide from the mycelium of an chinese edible fungus (Cordyceps sinensis). Carbohydr. Polym. 2006, 63, 251-256.

24. Zhao, C.; Li, M.; Luo, Y.F.; Wu, W.K. Isolation and structural characterization of an immunostimulating polysaccharide from fuzi, Aconitum carmichaeli. Carbohydr. Res. 2006, 341, 485-491. [CrossRef] [PubMed]

25. Carbonero, E.R.; Ruthes, A.C.; Freitas, C.S.; Utrilla, P.; Gálvez, J.; da Silva, E.V.; Sassaki, G.L.; Gorin, P.A.J.; Iacomini, M. Chemical and biological properties of a highly branched $\beta$-glucan from edible mushroom Pleurotus sajor-caju. Carbohydr. Polym. 2012, 90, 814-819.

26. Li, X.J.; Jiang, J.Y.; Shi, S.S.; Li, Y.; Jiang, Y.B.; Ke, Y.; Wang, S.C. Anti-complementary activities of a (1 $\rightarrow 6)$ linked glucan from korean mondshood root and its sulfated derivatives. Chem. J. Chin. Univ. Chin. 2014, $35,1423-1426$.

27. Cordeiro, L.M.; Reinhardt Vde, F.; Iacomini, M. Glucomannan and branched $(1 \rightarrow 3)(1 \rightarrow 6) \beta$-glucan from the aposymbiotically grown Physcia kalbii mycobiont. Phytochemistry 2012, 84, 88-93. [CrossRef] [PubMed]

28. Li, B.; Dobruchowska, J.M.; Hoogenkamp, M.A.; Gerwig, G.J. Structural investigation of an extracellular polysaccharide produced by the cariogenic bacterium Streptococcus mutans strain ua159. Carbohydr. Polym. 2012, 90, 675-682. [CrossRef] [PubMed]

29. Lammers, T.G. Revision of the infrageneric classification of Lobelia (Campanulaceae: Lobelioideae). Ann. MO. Bot. Gard. 2011, 98, 37-62. [CrossRef]

30. Chi, A.P.; Chen, J.P.; Wang, Z.Z.; Xiong, Z.Y.; Li, Q.X. Morphological and structural characterization of a polysaccharide from Gynostemma pentaphyllum makino and its anti-exercise fatigue activity. Carbohydr. Polym. 2008, 74, 868-874. [CrossRef]

31. Rudd, T.R.; Skidmore, M.A.; Guerrini, M.; Hricovini, M.; Powell, A.K.; Siligardi, G.; Yates, E.A. The conformation and structure of gags: Recent progress and perspectives. Curr. Opin. Struct. Biol. 2010, 20, 567-574. [CrossRef] [PubMed]

32. Yang, L.Q.; Zhang, L.M. Chemical structural and chain conformational characterization of some bioactive polysaccharides isolated from natural sources. Carbohydr. Polym. 2009, 76, 349-361. [CrossRef]

33. Brown, G.D.; Gordon, S. Immune recognition. A new receptor for $\beta$-glucans. Nature 2001, 413, 36-37. [CrossRef] [PubMed]

34. Rappleye, C.A.; Eissenberg, L.G.; Goldman, W.E. Histoplasma capsulatum $\alpha$-(1,3)-glucan blocks innate immune recognition by the $\beta$-glucan receptor. Proc. Natl. Acad. Sci. USA 2007, 104, 1366-1370. [CrossRef] [PubMed]

35. Wang, J.; Yuan, Y.; Yue, T. Immunostimulatory activities of $\beta$-D-glucan from Ganoderma lucidum. Carbohydr. Polym. 2014, 102, 47-54. [CrossRef] [PubMed]

36. Bittencourt, V.C.B.; Figueiredo, R.T.; da Silva, R.B.; Mourão-Sá, D.S.; Fernandez, P.L.; Sassaki, G.L.; Mulloy, B.; Bozza, M.T.; Barreto-Bergter, E. An $\alpha$-glucan of Pseudallescheria boydii is involved in fungal phagocytosis and toll-like receptor activation. Int. J. Biol. Macromol. Chem. 2006, 281, 22614-22623. [CrossRef] [PubMed]

37. Zhu, R.; Zhang, X.; Liu, W.; Zhou, Y.; Ding, R.; Yao, W.; Gao, X. Preparation and immunomodulating activities of a library of low-molecular-weight $\alpha$-glucans. Carbohydr. Polym. 2014, 111, 744-752. [CrossRef] [PubMed]

38. Dong, Q.; Yao, J.; Fang, J.N.; Ding, K. Structural characterization and immunological activity of two cold-water extractable polysaccharides from Cistanche deserticola y. C. Ma. Carbohydr. Res. 2007, 342, 1343-1349. [CrossRef] [PubMed]

39. Wang, Y.; Shen, X.; Liao, W.; Fang, J.; Chen, X.; Dong, Q.; Ding, K. A heteropolysaccharide, L-fuco-D-manno-1,6- $\alpha$-D-galactan extracted from Grifola frondosa and antiangiogenic activity of its sulfated derivative. Carbohydr. Polym. 2014, 101, 631-641. [CrossRef] [PubMed]

40. Xing, X.H.; Cui, S.W.; Nie, S.P.; Phillips, G.O.; Goff, D.H.; Wang, Q. Study on Dendrobium officinale O-acetyl-glucomannan (Dendronan ${ }^{\circledR}$ ): Part II. Fine structures of O-acetylated residues. Carbohydr. Polym. 2015, 117, 422-433. [CrossRef] [PubMed]

41. Fan, H.W.; Liu, F.; Bligh, S.W.; Shi, S.S.; Wang, S.C. Structure of a homofructosan from Saussurea costus and anti-complementary activity of its sulfated derivatives. Carbohydr. Polym. 2014, 105, 152-160. [CrossRef] [PubMed]

42. Liu, H.; Fan, Y.; Wang, W.; Liu, N.; Zhang, H.; Zhu, Z.; Liu, A. Polysaccharides from Lycium barbarum leaves: Isolation, characterization and splenocyte proliferation activity. Int. J. Biol. Macromol. 2012, 51, 417-422. [CrossRef] [PubMed] 
43. Parente, J.P.; Cardon, P.; Leroy, Y.; Montreuil, J.; Fournet, B.; Ricart, G. A convenient method for methylation of glycoprotein glycans in small amounts by using lithium methylsulfinyl carbanion. Carbohydr. Res. 1985, 141, 41-47. [CrossRef]

44. Duan, J.; Chen, V.L.; Dong, Q.; Ding, K.; Fang, J. Chemical structure and immunoinhibitory activity of a pectic polysaccharide containing glucuronic acid from the leaves of Diospyros kaki. Int. J. Biol. Macromol. 2010, 46, 465-470. [CrossRef] [PubMed]

45. Lin, X.; Wang, Z.J.; Sun, G.L.; Shen, L.; Xu, D.S.; Feng, Y. A sensitive and specific hpgpc-fd method for the study of pharmacokinetics and tissue distribution of Radix Ophiopogonis polysaccharide in rats. Biomed. Chromatogr. 2010, 24, 820-825. [CrossRef] [PubMed]

Sample Availability: Not available.

(C) 2016 by the authors; licensee MDPI, Basel, Switzerland. This article is an open access article distributed under the terms and conditions of the Creative Commons Attribution (CC-BY) license (http://creativecommons.org/licenses/by/4.0/). 